\title{
Biochemical Changes and Ponderal Weight After Administration of a Hyperlipidic Diet in Swiss Mice
}

\author{
Silva Júnior, P.R'; Almeida, L.R.B' ${ }^{2}$ Teófilo, P.B.E ${ }^{3}$; Arruda, I.T.S ${ }^{4}$; Oliveira, T.K.B ${ }^{5}$
}

${ }^{1,2,3}$ Student in Medicine by the Faculty of Medical Sciences of Campina Grande (FCM-CG); ${ }^{4} \mathrm{PhD}$ Student in Biotechnology of Health, focusing on Genetics, by the RENORBIO Program. ${ }^{5} \mathrm{Ph}$.D. Student of the Graduate Program in Agricultural Engineering, Federal University of Campina Grande UFCG. Professor at the Faculty of Medical Sciences of Campina Grande (FCM-CG).

\section{ABSTRACT}

A Introduction: The type of diet influences the metabolic functions and leads to changes in weight and/or body composition. Researchers have been trying to develop animal models in order to mimic the metabolic states of disorder that occur in humans. Aim: To analyze the metabolic changes after administration of a hyperlipid diet in Swiss mice. Methods: Twenty male Swiss mice weighing 39 - 44g with 120 days old were used. The control group (CG) was maintained on a standard balanced diet (Presence $\AA$ : $23 \%$ protein, $4 \%$ fat, $50 \%$ carbohydrate and $23 \%$ other components), whereas the experimental group (EG) received a special diet with formulation with a high fat content $(37.20 \%$ encephalon powder, $41.86 \%$ crushed feed, $18.60 \%$ lard and $2.32 \%$ cellulose). The Protocol was approved by the Ethics Committee on Animal Use (CEUA) of the Center for Higher Education and Development (CESED), with Protocol No. 2010/4573. The statistic was performed by Student's t-test. Results: The initial weight of the animals of the GC and GE groups were $383 \mathrm{~g}$ and $389 \mathrm{~g}$, respectively, and the final weight was $385 \mathrm{~g}$ and $424 \mathrm{~g}$, respective$\mathrm{ly}$, with a difference of $39 \mathrm{~g}$ more for the group that received only the hyperlipidic diet. Cholesterol analysis were $57.4 \pm 5.38$ for GC and $100.2 \pm 10.43$ for the GE, where $p=0.0013$, whereas for triglycerides values observed were of $50.4 \pm 16.62$ and 91, 91,6 \pm 30.6 respectively. Discussion: The hyperlipid diet significantly increased animal weight, plasma triglyceride concentration, and cholesterol. As demonstrated in other studies this diet was also efficient in increasing body adiposity in this study. Conclusion: The hyperlipidic diet elaborated in this study demonstrates as an excellent model for induction of obesity and dyslipidemia in mice. Keywords: High-fat Diet; Mice; Cholesterol; Triglycerides
${ }^{*}$ Correspondence to Author:

Silva Júnior, P.R

Student in Medicine by the Faculty of Medical Sciences of Campina Grande (FCM-CG)

How to cite this article:

Silva Júnior, P.R; Almeida, L.R.B; Teófilo, P.B.E; Arruda, I.T.S; Oliveira, T.K.B. Biochemical Changes and Ponderal Weight After Administration of a Hyperlipidic Diet in Swiss Mice. International Journal of Sports Medicine and Rehabilitation, 2018, 1:3

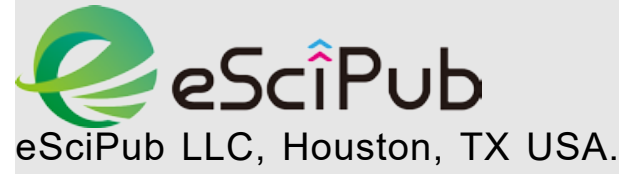

Website: http://escipub.com/ 